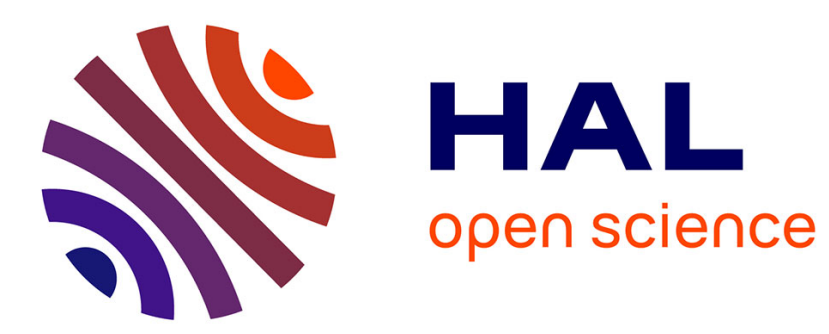

\title{
Responsibility to Protect (R2P)
}

\author{
Agathe Plauchut, Fabienne Le Houerou
}

\section{To cite this version:}

Agathe Plauchut, Fabienne Le Houerou. Responsibility to Protect (R2P). Paul Joseph. The SAGE Encyclopedia of War: Social Science Perspectives, SAGE Publications, pp.1464-1465, 2016, 9781483359892. 10.4135/9781483359878.n557 . hal-03517785

\section{HAL Id: hal-03517785 \\ https://hal.science/hal-03517785}

Submitted on 8 Jan 2022

HAL is a multi-disciplinary open access archive for the deposit and dissemination of scientific research documents, whether they are published or not. The documents may come from teaching and research institutions in France or abroad, or from public or private research centers.
L'archive ouverte pluridisciplinaire HAL, est destinée au dépôt et à la diffusion de documents scientifiques de niveau recherche, publiés ou non, émanant des établissements d'enseignement et de recherche français ou étrangers, des laboratoires publics ou privés. 


\section{@SAGE reference}

\section{The SAGE Encyclopedia of War: Social Science Perspectives}

Responsibility to Protect (R2P)

Contributors: Agathe Plauchut \& Fabienne Le Houérou

Edited by: Paul Joseph

Book Title: The SAGE Encyclopedia of War: Social Science Perspectives

Chapter Title: "Responsibility to Protect (R2P)"

Pub. Date: 2017

Access Date: November 22, 2016

Publishing Company: SAGE Publications, Inc.

City: Thousand Oaks,

Print ISBN: 9781483359892

Online ISBN: 9781483359878

DOI: http://dx.doi.org/10.4135/9781483359878.n557

Print pages: 1464-1465

(C2017 SAGE Publications, Inc.. All Rights Reserved.

This PDF has been generated from SAGE Knowledge. Please note that the pagination of the online version will vary from the pagination of the print book. 
During and after the Rwandan genocide in 1994, the international community was faced with its own powerlessness during a major crisis. Despite a UN peacekeeping force, the United Nations Assistance Mission for Rwanda (UNAMIR), being in the field, it did not have the means to stop the killings. In the few days following the beginning of the genocide, after 10 Belgian soldiers had been killed, the UN requested the withdrawal of the mission, and the number of soldiers eventually dropped from 2,500 to 270 . Major nations were unwilling to take the necessary steps to stop the genocide, which claimed approximately 800,000 lives in 100 days. After such a failure, the UN started to consider what went wrong and what could be changed about the way peacekeeping is designed and implemented.

New theories about sovereignty emerged in the aftermath. Before the Rwandan crisis, the absolute value was respect for state sovereignty. But after the Rwandan genocide, the interests of the people, what was called the "people's sovereignty," was advocated as a core value of the 21st century. Kofi Annan, secretary-general of the United Nations from 1997 to 2006, in a 1999 article in The Economist, conceptualized two sovereignties, the state's sovereignty and the people's sovereignty, as often matching but sometimes competing, when states become predatory and turn against their population. This led to the emergence of a movement regarding the theorization of a new concept that would better protect the rights of the people.

In September 2000, the Canadian government created the International Commission on Intervention and State Sovereignty (ICISS), co-chaired by Gareth Evans and Mohamed Sahnoun, with the objective of defining a new norm promoting humanitarian interventions and people's sovereignty's defense interventions. The ICISS produced a report in December 2001 titled "The Responsibility to Protect," which was to become the name of the emerging norm. In this report, sovereignty is considered a duty, with the state having the obligation to protect its citizens. If a state fails to do so, then the international community would have the duty to stand in for the state. The point here is that the international community should not focus on the security of states but rather on the security of the people living within the states. Put this way, the debate over sovereignty is overpassed by the reference to "people's sovereignty" instead of "state sovereignty."

\section{Conceptual as an International Norm}

The Responsibility to Protect (R2P) norm was thus originally designed to prevent genocide. The underlying idea is that when a major crisis is unfolding, there are warning signs that have to be addressed to prevent the situation from deteriorating further. This conception of the R2P thus asks for an ever-renewed attention on early signs and on peaceful ways to avoid the crisis. Coercive means are only one of the many categories of components included in the building of an international response to a growing crisis. The R2P norm thus echoes the peacebuilding/peacekeeping duality that already existed in the field of international responses to crisis.

R2P then became a noteworthy concept, influencing later international relations. It was adopted as an international norm during the 2005 UN World Summit, according to paragraphs 138 to 140 of the World Summit Outcome Document, which states that

each individual State has the responsibility to protect its populations from genocide, war crimes, ethnic cleansing and crimes against humanity. . . . The international community should, as appropriate, encourage and help States to exercise this 
responsibility. ... The international community, through the United Nations, also has the responsibility to use appropriate diplomatic, humanitarian and other peaceful means, in accordance with Chapters VI and VIII of the Charter, to help to protect populations from genocide, war crimes, ethnic cleansing and crimes against humanity. In this context, we are prepared to take collective action, in a timely and decisive manner, through the Security Council, in accordance with the Charter, including Chapter VII ... should peaceful means be inadequate and national authorities manifestly fail to protect their populations from genocide, war crimes, ethnic cleansing and crimes against humanity.

Both Kofi Annan and his successor as secretary-general of the United Nations Ban Ki-Moon supported the adoption and implementation of the R2P norm. In his 2009 report on R2P, KiMoon identified the three pillars of the R2P. The first pillar, the basic principle, deals with the state's responsibilities to protect its own citizens. It is a duty of the state to provide its people with a secure environment. The second pillar is about the international assistance that can be provided in order to build or enhance the capacities of a given state to fulfill its duty to protect. The third pillar relates to the situations in which the first two principles fail to be implemented and intends to foresee the actual reaction the international community can consider when a crisis erupts. It establishes, for instance, a responsibility for the international community to act as a surrogate of the state when it is unable or unwilling to protect its population.

Despite its fast success and expansion in the sphere of international relations theory, the R2P did not manage to be internationally recognized as law. It is still a principle, a norm, but has no mandatory dimension. The member states of the UN have the possibility to call upon the R2P to support their claim for humanitarian interventions, but the event of a humanitarian crisis or genocide does not force member states to take action to halt it. As a norm, the R2P provides a framework in which existing laws about human rights, genocide prevention, peace, stability and security, and sovereignty are considered together.

In the aftermath of the conceptualization of the R2P, other norms were imagined. A notable one was the Will to Intervene (W2I), also formulated in Canada. The fundamental argument of this new concept is that the R2P is a positive ideal but is not mandatory. Interventions in crisis situations will still rely on state interests. Therefore, the authors of the W2I report outlined that major powers should always have the desire to intervene when a crisis is erupting and when human rights are violated, because it is in their interest to promote peace and security. The essence of the idea is that insecurity somewhere, in a globalized context, produces instability everywhere. As a consequence, great powers should have the intention to intervene in foreign, even distant crises to protect the populations. This concept was defined as a continuation of the R2P, but it did not follow the same path and was not recognized as a norm. Nevertheless, it is interesting to observe how the conception of sovereignty and states' interests has shifted with the emergence of the R2P on the international relations stage.

\section{Examples}

In 2011, Libya was the first case in which the UN Security Council (UNSC) authorized an intervention involving military means citing the R2P as one of the elements of legitimacy of the mission. In 2013-2014, the R2P principle was mentioned in the case of the Central African Republic, when the situation there dramatically deteriorated. The UNSC's resolution, which authorized French intervention, was inspired and theoretically supported by the R2P principle. The persisting and sporadically erupting battles in Darfur and South Sudan also convinced certain experts to require the R2P option in that humanitarian crisis. 
Following the breakthrough of the Islamic State of Iraq and Syria (ISIS, also known as ISIL or Daesh), the humanitarian crisis that struck the two countries led some diplomats and observers to call upon the R2P principles to bring about an international intervention. Tens of thousands of people died in the years following the insurrection and hundreds of thousands were displaced, unprotected by their governments. Crimes against humanity were committed, but when the international coalition against ISIS, led by the United States, was formed in late 2014 , no direct reference to the R2P was made-perhaps because a formal appeal to the $\mathrm{R} 2 \mathrm{P}$ principles would require a deeper involvement of coalition members, many of which do not wish to send in soldiers.

\section{Criticisms}

Critical views against R2P have emerged since it was conceptualized. Some observers offer that it has been misused or expanded beyond its objectives. In some cases, R2P was called upon to justify certain interventions whereas other humanitarian crises were left unmanaged. This was particularly evident during the military intervention in Libya. Great concerns have thus risen about the possible use of $\mathrm{R} 2 \mathrm{P}$ as a tool for imperialist interventions, giving the leaders of the great powers the opportunity to voice noble intentions while also promoting national interests. The confusion between political and humanitarian purposes can thus tarnish the activation of the R2P doctrine, maybe because nobody has the naivety to believe in the state's good will to intervene when no interest is at risk.

See alsoCrimes Against Humanity; Genocide; Libya; Rwanda

Agathe PlauchutFabienne Le Houérou

http://dx.doi.org/10.4135/9781483359878.n557

10.4135/9781483359878.n557

\section{Further Readings}

Ban, Ki-Moon. Implementing the Responsibility to Protect. New York: United Nations, 2009.

Dallaire, Roméo, and Franck Challak. Mobilizing the Will to Intervene: Leadership and Action to Prevent Mass Atrocities. Montreal: Montreal Institute for Genocide and Human Rights Studies, 2009.

Le Houérou, Fabienne. International Relations and Humanitarian Crises. Oak Park, IL: Bentham Science Publishers, 2014.

ICISS. The Responsibility to Protect. Ottawa: The International Development Research Centre, 2001.

United Nations. Resolution 60/1: 2005 World Summit Outcome. http://www.un.org/womenwatch/ods/A-RES-60-1-E.pdf. 